\title{
Values of serum carcinoembryonic antigen and elastase 1 in diagnosis of pancreatic carcinoma
}

\author{
M TATSUTA, H YAMAMURA, S NOGUCHI, M ICHII, \\ H IISHI, AND S OKUDA \\ From the Departments of Gastrointestinal Oncology and Gastroenterology, The Center for Adult Diseases, \\ Osaka, Japan
}

SUMmary Carcinoembryonic antigen (CEA) and elastase 1 in the serum were determined by enzyme immunoassay and radioimmunoassay, respectively, in 224 healthy subjects, 49 patients with pancreatitis, 53 patients with pancreatic carcinoma and 129 patients with cancer in other organs. The CEA concentrations in the serum were significantly higher in patients with pancreatic carcinoma than in those with pancreatitis, but this concentration was not a satisfactory indicator of pancreatic carcinoma localised to allow irradication by resection as it was raised in only $47 \%$ of the patients. High CEA concentrations were also slightly, but not significantly, more frequent in patients with cancer of the pancreatic body or tail, and unresectable cancer or cancer of more than $6.0 \mathrm{~cm}$ in longest diameter than in those with cancer of the pancreatic head, resectable cancer or cancer of less than $6.0 \mathrm{~cm}$ diameter. Serum elastase 1 was raised in only $42 \%$ of the patients with pancreatic carcinoma and could not be used to distinguish patients with pancreatic carcinoma from those with pancreatitis. In contrast with CEA, however, its concentration was abnormally high significantly more frequently in patients with cancer of less than $6.0 \mathrm{~cm}$ in longest diameter than in those with larger tumours. It was also raised slightly, but not significantly, more frequently in those with cancer of the pancreatic head and in patients with resectable cancer than in those with unresectable cancer. A combination of these two tests raised the diagnostic rate of pancreatic carcinoma to $77 \%$ without a remarkable decrease in the specificity for pancreatic carcinoma. In particular, it raised the diagnostic rates of cases of cancer of the pancreatic head, resectable cancer and cancers of less than $3.0 \mathrm{~cm}$ and $3.0-6.0 \mathrm{~cm}$ in longest diameter. Therefore, a combination of measurements of CEA and elastase 1 in the serum is very useful for early detection of pancreatic carcinoma.

Although many techniques are available for diagnosis of pancreatic carcinoma, early diagnosis of this tumour is still very difficult. Increase in the carcinoembryonic antigen (CEA) $)^{1}$ concentration in the serum is not a satisfactory indicator of early pancreatic carcinoma when taken in isolation, ${ }^{2-5}$ and must be assayed in combination with other serum markers for diagnosis of pancreatic carcinoma. ${ }^{67}$ Elastase, a protease present in pancreatic tissue, was first reported in 1952 by Banga, ${ }^{89}$ and recently, abnormally high concen-

Address for correspondence: Masaharu Tatsuta, MD, Department of Gastrointestinal Oncology, The Center for Adult Diseases, Osaka, 3-3, Nakamichi 1-chome, Higashinari-ku, Osaka 537, Japan.

Received for publication 21 February 1984 trations of elastase 1 have been found in the serum of patients with pancreatic carcinoma. ${ }^{1011}$

Therefore, we examined the value of assays of both serum CEA and elastase 1 for diagnosis of pancreatic carcinoma.

\section{Methods}

PATIENTS

Carcinoembryonic antigen (CEA) and elastase 1 in the serum were determined by enzyme immunoassay and radioimmunoassay respectively, in 224 healthy subjects, 49 patients with pancreatitis, 53 patients with pancreatic carcinoma and 129 patients with cancer in other organs. The patients with pancreatic carcinoma consisted of 38 men and 15 
women, with an average age of 64.3 years (range, 42-85 years). The histological and/or cytological diagnosis was verified at laparotomy or at necropsy in all patients with pancreatic carcinoma. The sizes of tumours were measured in specimens obtained by pancreatectomy of 21 resectable tumours. The patients with pancreatitis had two or more of the following features: a clinical history of chronic continuous or relapsing pancreatic pain; more than two documented attacks of acute pancreatitis; pancreatic calcification; abnormal results in a pancreatin-secretin test; abnormal ultrasonic findings or a positive endoscopic retrograde pancreatogram. Radiological, endoscopic and cytological examinations revealed no clinical signs of malignant disease in any of the patients with pancreatitis. The healthy subjects were patients with no evidence of symptoms who underwent mass survey examination for cancer of the stomach, the pancreas and the liver, but who were found to be normal on laboratory investigation, and ultrasonographic and roentogenographic investigation, sometimes including endoscopic pancreatography. The patients with cancer in other organs consisted of 25 patients with gastric carcinoma, 14 patients with colon cancer, 21 patients with hepatocellular carcinoma, 23 patients with pulmonary cancer, 20 patients with breast cancer, 17 patients with laryngeal cancer and nine patients with urogenital cancer.

Peripheral blood specimens were collected from the subjects after overnight fasting. The sera obtained were promptly stored at $-20^{\circ} \mathrm{C}$ and used for assay of CEA and elastase 1 within one week. Carcinoembryonic antigen was measured by enzyme immunoassay with an assay kit from Abbott Laboratories (North Chicago, USA) by the procedure reported previously. ${ }^{12}{ }^{13}$ As little as $1.0 \mathrm{ng}$ of CEA per millilitre of serum could be detected.

Elastase 1 was measured by the radioimmunoassay technique with an assay kit from Dainabot Co Ltd (Tokyo, Japan) as follows: ${ }^{11}$ serum samples $(0 \cdot 1$ $\mathrm{ml}$ ) or standard amounts of elastase 1 were assayed in duplicate. A mixture of $0.1 \mathrm{ml}$ of serum, $0.1 \mathrm{ml}$ of diluted antiserum and $1.0 \mathrm{ml}$ of ${ }^{125}$ I-labelled elastase 1 was incubated at $37^{\circ} \mathrm{C}$ for three hours. Then $5.0 \mathrm{ml}$ of goat antiserum to rabbit IgG was added, and the mixture was kept at room temperature for more than 10 minutes and then centrifuged at $3000 \mathrm{rpm}$ for 20 minutes. After careful aspiration of the supernatant, the radioactivity in the pellet was measured quantitatively, in a scintillation counter. As little as $50 \mathrm{ng} / \mathrm{dl}$ of elastase 1 per $\mathrm{ml}$ of serum could be detected by this assay.

Data are given as mean \pm SEM, and Student's $t$ test,${ }^{14} \chi^{2}$ test or Fisher's exact probability test ${ }^{15}$ was used to analyse the results. The word 'significant' indicates a calculated $p$ value of less than 0.05 . In the present paper, the terms 'sensitivity' and 'specificity' are used. ${ }^{16}$ 'Sensitivity' is the ability of a test to give a positive result when the subject tested has the condition under study. 'Specificity' is the ability of the test to give a negative result when the subject tested is free from the condition under study. The ideal test should be $100 \%$ sensitive and $100 \%$ specific.

\section{Results}

SERUM CEA, ELASTASE I AND A COMBINATION OF THESE TWO MARKERS FOR DETECTION OF

PANCREATIC CARCINOMA

Data on serum CEA, elastase 1 and a combination of these two markers in healthy subjects, patients with benign and malignant pancreatic diseases and patients with cancer in other organs are summarised in Table 1.

The CEA concentration in the serum was significantly higher in patients with benign and malignant pancreatic diseases and in patients with cancer in other organs than in healthy subjects. The serum CEA concentration was significantly higher in patients with pancreatic carcinoma than in those with pancreatitis, while the difference in mean values between patients with pancreatic carcinoma and with cancer in other organs was not statistically significant. The serum elastase 1 concentrations were also significantly higher in patients with benign and malignant pancreatic diseases and in patients with cancer in other organs than in healthy subjects. Although the elastase 1 concentration in the serum was significantly higher in patients with pancreatic carcinoma than in those with cancer in other organs, the difference in mean values between patients with

Table 1 Serum CEA and elastase 1 concentrations

\begin{tabular}{lccl}
\hline Group & $\begin{array}{l}\text { Subjects } \\
\text { (no) }\end{array}$ & $\begin{array}{l}\text { Serum CEA } \\
(\text { mean } \pm \text { SEM })\end{array}$ & $\begin{array}{l}\text { Elastase 1 } \\
\text { (mean } \pm \text { SEM) }\end{array}$ \\
\hline Healthy subjects & 224 & $2 \cdot 0 \pm 0 \cdot 1$ & $223 \cdot 7 \pm 6 \cdot 0$ \\
Pancreatic carcinoma & 53 & $8 \cdot 8 \pm 1 \cdot 4^{*}$ & $618 \cdot 2 \pm 95 \cdot 1 \dagger$ \\
Pancreatitis & 49 & $3 \cdot 0 \pm 0 \cdot 3 \ddagger$ & $468 \cdot 3 \pm 62 \cdot 5 \ddagger$ \\
Cancer in other organs & 129 & $10 \cdot 1 \pm 1 \cdot 7 \ddagger$ & $321 \cdot 2 \pm 15 \cdot 1 \ddagger$ \\
\hline
\end{tabular}

* Significantly different $(p<0.001)$ from values for healthy subjects and patients with pancreatitis, but not from that for patients with cancer in other organs (Student's $t$ test).

† Significantly different $(p<0.001)$ from values for healthy subjects and patients with cancer in other organs, but not from that for patients with pancreatitis (Student's $t$ test).

$\ddagger$ Significantly different $(p<0.001)$ from the value for healthy subjects (Student's $t$ test). 
pancreatic carcinoma and with pancreatitis was not statistically significant.

Of the sera obtained from 224 healthy subjects, $217(97 \%)$ had CEA concentrations of less than 5.0 $\mathrm{ng} / \mathrm{ml}$ and all had elastase 1 concentrations of less than $500 \mathrm{ng} / \mathrm{dl}$. Therefore, in this study, abnormally high CEA and elastase 1 concentrations in the serum were defined as those of more than $5.0 \mathrm{ng} / \mathrm{ml}$ and $500 \mathrm{ng} / \mathrm{dl}$, respectively. As shown in Table 2, correct diagnoses of pancreatic carcinoma were made in $47 \%$ of the cases by CEA measurement alone and in $42 \%$ of the cases by measurement of elastase 1 alone. That is, the sensitivities of measurements of CEA alone and elastase 1 alone for detection of pancreatic carcinoma were $47 \%$ and $42 \%$, respectively, and the specificities of measurements of CEA alone and elastase 1 alone for detection of pancreatic carcinoma were $83 \%$ and $95 \%$, respectively.

Abnormally higher CEA and/or elastase 1 concentrations in the serum were significantly more frequent in patients with benign or malignant pancreatic disease and in those with cancer in other organs than in healthy subjects. Serum high CEA and/or elastase 1 concentrations were significantly more frequent in patients with pancreatic carcinoma than in those with pancreatitis and with cancer in other organs. Assay of both parameters raised the diagnostic rate to $77 \%$. There was little or no difference between the frequencies of abnormally high levels of serum CEA and abnormally high concentrations of serum CEA and/or elastase 1 in healthy subjects or patients with cancer in other organs. Although abnormally high concentrations in cases of pancreatitis were increased from $14 \%$ by CEA measurement alone to $35 \%$ by measurement of both markers, the overall specificity of a combination of CEA and elastase 1 measurements for pancreatic carcinoma decreased only from $83 \%$ by CEA measurement alone to $80 \%$ by measurement of both markers.

RELATIONS OF SERUM CEA, ELASTASE I AND A COMBINATION OF THESE TWO MARKERS TO THE LOCATION, RESECTABILITY AND SIZE OF

PANCREATIC CARCINOMA

Table 3 summarises the relations of the CEA and elastase 1 concentrations and a combination of both to the location, resectability and size of pancreatic carcinoma. Measurement of CEA in the serum was not a satisfactory indicator of pancreatic carcinoma localised to allow irradication by resection. High serum CEA concentrations were slightly, but not significantly, more frequent in patients with cancer of the body or tail, in patients with unresectable cancer and in cases with a tumour of more than 6.0 $\mathrm{cm}$ in longest diameter than in those with cancers of the head of the pancreas, those with resectable cancer and those with a tumour of less than $6.0 \mathrm{~cm}$ in diameter. In contrast, measurement of elastase 1 was useful for early detection of pancreatic cancer. Abnormally high elastase 1 concentrations were seen significantly more frequent in patients with a tumour of less than $6.0 \mathrm{~cm}$ in diameter than in those with a tumour of more than $6.0 \mathrm{~cm}$ in diameter. High serum elastase 1 concentrations were also found more frequently in patients with a tumour of the head of the pancreas and in those with resectable cancer than in those with a tumour of the body or tail and in those with unresectable cancer; although the differences were not statistically significant. The combined assay raised the diagnostic rates for cases

Table 2 Serum CEA, elastase 1 concentrations and a combination of these two markers

\begin{tabular}{|c|c|c|c|c|}
\hline Group & $\begin{array}{l}\text { Subjects } \\
\text { (no) }\end{array}$ & $\begin{array}{l}\text { High serum } C E A \\
(>5.0 \mathrm{ng} / \mathrm{ml})\end{array}$ & $\begin{array}{l}\text { High serum elastase } 1 \\
(>500 \mathrm{ng} / \mathrm{dl})\end{array}$ & $\begin{array}{l}\text { High serum } C E A \\
(>5.0 \mathrm{ng} / \mathrm{ml}) \\
\text { and } / \text { or } \\
\text { High serum elastase } 1 \\
(>500 \mathrm{ng} / \mathrm{dl})\end{array}$ \\
\hline Healthy subjects & 224 & $7(3 \%)$ & $0(0 \%)$ & $7(3 \%)$ \\
\hline Pancreatic carcinoma & 53 & $25(47 \%)^{*}$ & $22(42 \%) \dagger$ & $41(77 \%) \ddagger$ \\
\hline Pancreatitis & 49 & $7(14 \%) \S$ & $11(22 \%) \S$ & $17(35 \%) \S$ \\
\hline Cancer in other organs & 129 & $54(42 \%) \S$ & $8(6 \%) \S$ & $57(44 \%) \S$ \\
\hline Sensitivity for pancreatic carcinoma & & $47 \%(25 / 53)$ & $42 \%(22 / 53)$ & $77 \%(41 / 53)$ \\
\hline Specificity for pancreatic carcinoma & & $83 \%(334 / 402)$ & $95 \%(383 / 402)$ & $80 \%(321 / 402)$ \\
\hline
\end{tabular}

* Significantly different $(\mathrm{p}<0.001)$ from values for healthy subjects and patients with pancreatitis, but not from that for patients with cancer in other organs $\left(\chi^{2}\right.$ test $)$.

+ Significantly different $(p<0.001)$ from values for healthy subjects and patients with cancer in other organs, but not from that for patients with pancreatitis $\left(\chi^{2}\right.$ test $)$.

$\ddagger$ Significantly different $(\mathrm{p}<0.001)$ from the value for healthy subjects, patients with pancreatitis and those with cancer in other organs $\left(\chi^{2}\right.$ test $)$.

$\S$ Significantly different $(p<0 \cdot 001)$ from the value for healthy subjects $\left(\chi^{2}\right.$ test $)$. 
Table 3 Serum CEA, elastase 1 concentrations and a combination of these two markers in patients with pancreatic carcinoma

\begin{tabular}{|c|c|c|c|c|c|}
\hline Cancer & & $\begin{array}{l}\text { Subjects } \\
\text { (no) }\end{array}$ & $\begin{array}{l}\text { High serum } C E A \\
(>5.0 \mathrm{ng} / \mathrm{ml})\end{array}$ & $\begin{array}{l}\text { High serum elastase } 1 \\
(>500 \mathrm{ng} / \mathrm{dl})\end{array}$ & $\begin{array}{l}\text { High serum CEA } \\
(>5.0 \mathrm{ng} / \mathrm{ml}) \\
\text { and/or } \\
\text { High serum elastase } 1 \\
(>500 \mathrm{ng} / \mathrm{dl})\end{array}$ \\
\hline \multirow[t]{2}{*}{ Location } & Head & 35 & $14(40 \%)$ & $17(49 \%)$ & $27(77 \%)$ \\
\hline & Body and tail & 18 & $11(61 \%)$ & $5(28 \%)$ & $14(78 \%)$ \\
\hline Resectability & Unresectable & 32 & $18(56 \%)$ & $12(38 \%)$ & $26(81 \%)$ \\
\hline \multirow[t]{3}{*}{ Size } & Less than $3.0 \mathrm{~cm}$ & 5 & $0(0 \%)$ & $4(80 \%)$ & $4(80 \%)$ \\
\hline & $3 \cdot 0-6 \cdot 0 \mathrm{~cm}$ & 10 & $3(30 \%)$ & $6(60 \%)$ & $7(70 \%)$ \\
\hline & More than $6.0 \mathrm{~cm}$ & 6 & $4(67 \%)$ & $0(0 \%)^{*}$ & $4(67 \%)$ \\
\hline
\end{tabular}

* Significantly different $(p<0.01)$ from values for cases with tumours of less than $6.0 \mathrm{~cm}$ in diameter (Fisher's exact probability test).

with cancer of the head of the pancreas, resectable cancer and cancers of less than $3.0 \mathrm{~cm}$ and 3.0-6.0 $\mathrm{cm}$ in longest diameter from $40 \%, 33 \%, 0 \%$, and $30 \%$, respectively, by CEA measurement alone to $77 \%, 71 \%, 80 \%$ and $70 \%$, respectively.

\section{Discussion}

Elastase is unique among the proteases present in pancreatic tissue and pancreatic secretions in causing rapid hydrolysis of elastin, a fibrous, insoluble protein of connective tissue. ${ }^{9}$ Banga $^{8}$ in 1952 first isolated this enzyme from the pancreas. The ability of elastase to digest elastin had led to suggestions that this enzyme may be implicated in vascular injury in acute pancreatic necrosis. ${ }^{17}$ Attempts by numerous investigators to measure elastase activity in serum by enzymatic methods have failed because of lack of a sufficiently sensitive method, the use of unsuitable dyed elastin as substrate, and the high concentration of protease inhibitors in the blood. ${ }^{9}$ Recently, however, pancreatic elastase 1 was determined by a radioimmunoassay technique. ${ }^{1011}$ Using this method, Satake et al $^{11}$ found that the serum elastase 1 concentrations in patients with acute, acute relapsing, and chronic relapsing pancreatitis were significantly raised. They showed that the serum elastase 1 concentration decreased more gradually and remained higher for longer than the serum amylase concentration in patients with pancreatitis. Kimura ${ }^{10}$ also obtained similar results; he found that serum elastase 1 was not increased in cases of hyperamylasaemia, except in those of acute pancreatitis. It was concluded from these findings that measurement of serum elastase 1 by the immunoassay technique is very useful in diagnosis of pancreatic diseases.

Satake et $a l^{11}$ reported that $12(63 \%)$ of 19 patients with pancreatic cancer had raised elastase 1 concentrations and in particular, nine $(90 \%)$ of 10 patients with cancer of the head of the pancreas had high concentrations. We obtained similar results: 22 $(42 \%)$ of 53 patients with pancreatic cancer had abnormally high elastase 1 concentrations in the serum. We also found that the serum elastase 1 concentrations were significantly higher in patients with cancer of less than $6.0 \mathrm{~cm}$ in longest diameter than in those with cancer of more than $6.0 \mathrm{~cm}$ in diameter. Obstruction of the pancreatic duct by the tumour probably results in liberation of the enzyme into the blood, but it is unknown why the elastase 1 concentrations were high in patients with pancreatic carcinoma in an early stage. Measurement of elastase 1 in the serum was not of value in distinguishing pancreatic carcinomas from pancreatitis, but measurement of elastase 1 in the serum was useful in diagnosis of pancreatic diseases. Therefore, it could be a useful method for early detection of pancreatic carcinoma when sensitive tumour markers are measured simultaneously. To test this idea, we examined the value of measuring both serum CEA and elastase 1 concentrations in diagnosis of pancreatic carcinoma.

Because the concentration of CEA in the serum has not proved satisfactory as an indicator of early detection of pancreatic carcinoma, combined measurements of CEA and other tumour markers have been carried out. ${ }^{67}$ We measured CEA in pancreatic juice obtained by endoscopic cannulation of the papilla of Vater, ${ }^{18}$ bile obtained by percutaneous transhepatic cholangiography ${ }^{19}$ and pancreatic materials collected by ultrasonically guided percutaneous aspiration biopsy of the pancreas $^{20}$ for early diagnosis of pancreatic carcinoma. In the present study, we obtained correct diagnoses in $47 \%$ of the cases by measurement of serum CEA only, in $42 \%$ of the cases by 
measurement of elastase 1 , and in $77 \%$ of the cases by a combination of these two tests and this combination of tests for pancreatic carcinoma did not decrease the specificity remarkably. In particular, the combination of assays raised the diagnostic rate for cases of cancer of the pancreatic head, resectable cancer and cancer of less than 3.0 $\mathrm{cm}$ and $3.0-6.0 \mathrm{~cm}$ in longest diameter to $77 \%$, $71 \%, 80 \%$, and $70 \%$, respectively. Therefore, a combination of measurements of CEA and elastase 1 in the serum seems very useful for early detection of pancreatic carcinoma. In practice, patients with high CEA and/or elastase 1 concentrations were examined more extensively by ultrasonographic and computed tomographic investigations or endoscopic retrograde pancreatography, thus reducing the rate of overlooking cases of pancreatic carcinoma. In this series, $21(40 \%)$ of 53 cases of pancreatic cancer were still sufficiently localised to allow irradication by resection.

This work was supported in part by the Grant-inAid for Cancer Research (58-20) from the Ministry of Health and Welfare.

\section{References}

1 Gold P, Freedman SO. Demonstration of tumorspecific antigens in human colonic carcinomata by immunological tolerance and absorption technique. J Exp Med 1965; 121: 439-62.

2 Barkin JS, Kalser MH, Kaplan R, Redlhammer D, Heal A. Initial levels of CEA and their rate of change in pancreatic carcinoma following surgery, chemotherapy and radiation therapy. Cancer 1978; 42: 14726.

3 Ravry M, Moertel CG, Schutt AJ, Go VLW. Usefulness of serial serum carcinoembryonic antigen (CEA) determinations during anticancer therapy or long term follow up of gastrointestinal carcinoma. Cancer 1974; 34: $1230-4$.

4 Skarin AT, Delwiche R, Zamcheck N, Lokich JJ, Frei E III. Carcinoembryonic antigen: clinical correlation with chemotherapy for metastatic gastrointestinal cancer. Cancer 1974; 33: 1239-45.

5 Zamcheck N, Martin EW. Factors controlling the circulating CEA levels in pancreatic cancer: some clinical correlations. Cancer 1981; 47: 1620-7.
6 Bender RA, Weintraub BD, Rosen SW. Prospective evaluation of two tumor-associated proteins in pancreatic adenocarcinoma. Cancer 1979; 43: 591-5.

7 Nishida K, Yoshikawa T, Kondo M, Thiele HG. Immunological diagnosis of pancreatic cancer by assaying carcinoembryonic antigen (CEA) in pure pancreatic juice. Hepato-Gastroenterol 1980; 27: 488494.

8 Banga I. Isolation and crystallisation of elastase from the pancreas of cattle. Acta Physiol Acad Sci Hung 1952; 3: 317-24.

9 Geokas MC, Brodrick JW, Johnson JH, Largman C. Pancreatic elastase in human serum. Determination by radioimmunoassay. J Biol Chem 1977; 252: 61-7.

10 Kimura T. Studies on elastase in pancreatic disease. Jpn J Gastroenterol 1975; 76: 84-96.

11 Satake K, Chung Y-S, Umeyama K. Serum elastase 1 levels in pancreatic disease. Am J Surg 1982; 144: 239-42.

12 Maiolini R, Bargrel A, Chavance C, Krebs B, Herbeth B, Masseyeff R. Study of an enzyme immunoassay kit for carcinoembryonic antigen. Clin Chem 1980; 26: 1718-22.

13 Tatsuta M, Itoh T, Okuda S, Yamamura H, Baba M, Tamura H. Carcinoembryonic antigen in gastric juice as an aid in diagnosis of early gastric cancer. Cancer 1980; 46: 2686-92.

14 Snedecor GW, Cochran WG. Statistical methods. Ames Iowa: The Iowa State University Press, 1967: 104-6.

15 Siegel S. Nonparametric statistics for the behavioral sciences. New York: McGraw-Hill Book Co, 1956: 96-111.

16 MacMahon B, Pugh TF. Epidemiology: principles and methods. Boston: Little, Brown and Co, 1976: 261.

17 Geokas MC, Rinderknecht H, Swanson V, Haverback BJ. The role of elastase in acute hemorrhagic pancreatitis in man. Lab Invest 1968; 19: 235-9.

18 Tatsuta $M$, Yamamura $H$, Yamamoto R, Okano Y, Morii T, Tamura H. Significance of carcinoembryonic antigen levels and ctyology of pure pancreatic juice in diagnosis of pancreatic cancer. Cancer 1983; 52: 18805.

19 Tatsuta $M$, Yamamura $H$, Yamamoto $R$, Morii $T$, Okuda S, Tamura $\mathrm{H}$. Carcinoembryonic antigen in the bile in patients with pancreatic and biliary cancer. Cancer 1980; 50: 2903-9.

20 Tatsuta $M$, Yamamoto R, Yamamura H, Okuda S, Tamura $H$. Cytological examination and CEA measurement in aspirated pancreatic material collected by percutaneous fine-needle aspiration biopsy under ultrasonic guidance for the diagnosis of pancreatic carcinoma. Cancer 1983; 52: 693-8. 